v. $12, n .1$

Vitória-ES, Jan.-Feb. 2015

p. $128-153$ ISSN 1808-2386

DOI: http://dx.doi.org/10.15728/bbr.2015.12.1.6

\title{
The Structure of Artefacts of Management Control in the Innovation Process: Does Exist Association with the Strategic Profile?
}

\author{
Fábio Frezatti \\ Universidade de São Paulo \\ Diógenes de Souza Bido ${ }^{\Omega}$ \\ Universidade Presbiteriana Mackenzie \\ Ana Paula Capuano da Cruz ${ }^{¥}$ \\ Universidade Federal do Rio Grande \\ Maria José de Camargo Machado \pm \\ Universidade Metodista de Piracicaba
}

\begin{abstract}
This study investigates what is the role of strategic profiles and management control instruments in organisations' innovation process. Based in a survey using structural equation modelling (121 companies), we confirm that analyser, defender e prospector profiles are associated with strategic planning, balanced scorecard (BSC) and rolling forecast. The reactor type is associated with lower use of artefacts. Our results confirm the linkage between incremental innovation and strategic planning and between radical innovation and BSC. These findings reflect the alignment between strategic types, the availability of instruments and intensity of innovation, which is useful information with which to understand organisations and their market activities. This paper bring information about specific management control instruments existence and the impact for the intensity of the innovation that is relevant for management and must stimulate organizations to be consistent in the cases that the strategic profile is a clear long term definition or see the possibility of change when it is not the desired one.
\end{abstract}

Keywords: Innovation process. Strategic profile. Management control instruments.

Received on 09/03/2013; reviewed on 12/27/2013; accepted on 01/16//2014; published on 02/05/2015

* Author for correspondence:

${ }^{\dagger}$. Doctor in Management by Universidade de São Paulo

Type of contract:

Professor in Universidade de São Paulo

Address: Av. Prof. Luciano

Gualberto,

São Paulo - SP - Brazil

Email: frezatti@usp.br

Telephone: (11) 3091-5820

Note from the editor: This article was accepted by Emerson Mainardes.
$\Omega$ Doctor in Management by Universidade de São Paulo Type of contract: Professor in Universidade Presbiteriana Mackenzie

Address: Av. Santo Antônio,

Osasco - SP - Brazil

Email:

diogenesbido@yahoo.com.br

Telephone: (11) 2114-8260

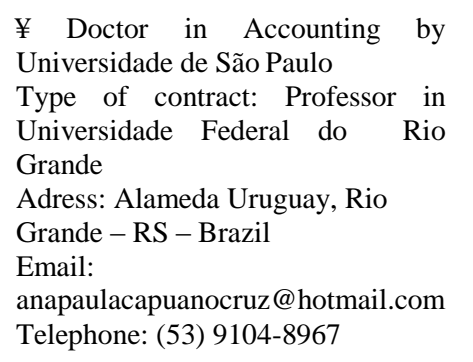

$¥$ Doctor in Accounting by
Universidade de São Paulo
Type of contract: Professor in
Universidade Federal do Rio
Grande
Adress: Alameda Uruguay, Rio
Grande - RS - Brazil
Email:
anapaulacapuanocruz@ hotmail.com
Telephone: (53) 9104-8967

\pm Measter in Accounting by Universidade de São Paulo Type of contract: Professor in Universidade Metodista de Piracicaba

Address: Prudente de Moraes,São Paulo SP - Brazil

Email:mjzen@terra.com.br mjczen@gmail.com Telephone: (19) 8292-8777

\section{(cc) $\mathrm{E}$}

This article has a Creative Commons License - Attribution 3.0 Not Adapted. 



\section{INTRODUCTION}

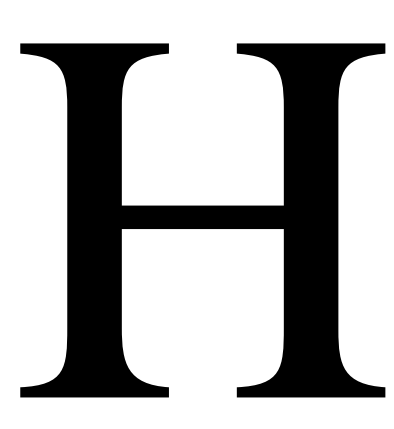

uman knowledge develops cumulatively; i.e., each new contribution complements a previously developed contribution. Breakthroughs sometimes occur that lead to very distinct new approaches. Thereafter, new knowledge is presented, added and developed. Sometimes, it is fundamental to return to the past and rescue the origin to achieve new advances. In this sense, a relevant contribution exists when one perceives that organisations have the right to continue existing (SIMONS, 1995), provided that they offer some type of benefit to the environment. Therefore, organisations must always present themselves proactively to conquer, re-conquer and maintain their space in the business environment, which demands different types of resources. Based on Simons (1995), the innovation process can be understood as the way in which an organisation demonstrates that it is ready to operate in the market and perpetuate its existence.

Thus, innovation is not always pursued by organisations in a structured manner, but innovation should nevertheless be part of these organisations' daily routine as a type of longterm maintenance. Innovation influences firm's risk, direction and long-term self-definition and even the way in which the firm communicates its impact on future decisions. Therefore, innovation is expected to be a relevant theme in discussions about business, formal and informal planning and results. Consequently, the theme becomes part of organisations' management model. The way in which these organisations develop and control the innovation process is relevant for their worldview and perspective of success (NGO; O'CASS, 2013).

Organisations' management model demands instruments that enable the planning and development of their activities. The structuring of the planning process itself is relatively complex, to the extent that it involves the different hierarchical levels of company structure and several organisational areas. Although the theme is discussed in some papers (REVELLINO; MOURITSEN, 2009), instruments are not treated separately. Accordingly, the question guiding this research is as follows: what is the role of strategic profiles and management control instruments in organisations' innovation process?

This study adopted the typology of Miles and Snow (2003), which defines four different profiles: defender, prospector, analyser and reactor. Although the typology was developed long time ago (MILES; SNOW, 1978), it is currently used for many perspectives including management control issues (MORGAN; STRONG, 2003; HYVÖNEN, 2007; NARANJOGIL; HARTMANN, 2007; MACINTOSH; QUATTRONE, 2010). Despite the usage some 
criticism were raised due to the fact of some dimensions of the organizations are excluded of the model (MORGAN; STRONG, 2003). Additionally, the prior understanding that controls contributed negatively to innovation (SIMONS, 1987) and that now is seen differently, is an important change that made the look of control system by other perspective and create an opportunity to review the literature and empirical data. It doesn't matter the perspective, innovation management but it is fragmented thru the organization and due to this the studies are too what makes difficult to incorporate in a single framework so many issues (ADAMS; BESSANT; PHELPS, 2006).

The literature indicates that each profile has distinct characteristics and also reflects management control instruments (MACINTOSH; QUATTRONE, 2010). It is expected that the control systems is congruent with the strategy (SIMONS, 1987). On the other hand, Simons (1987) found different emphasis in the way that tools were used, that attributed certain level of qualification for the instrument. Timing, technology, radical changes in the management requires update of this issue splitting the elements. This way, with the methodological alignment of this paper it will restrict the field research to the existence of the tools.

Strategic planning, budget, rolling forecast and budget control are instruments that permit the implementation and control of these innovation processes. Frequent criticism of this set of instruments refers to the way in which they may implement decisions and the manner in which they are managed. Periodically, some type of monitoring and performance assessment occurs, whether at the individual or organisational level, with the degrees of formalisation demanded by the management model.

The availability of strategic planning, the Balanced Scorecard, budgets, rolling forecast and budget control constitute a set of relevant elements to formalise the implementation of the strategies and thus to organise the innovation process behind it. In a practical sense, some instrument is expected to be available that permits an acceptable level of association between the decisions that are verified in strategic planning and implemented through the budget, including the consequent monitoring and assessment in a budget control model.

Based in an online survey and using structural equation modeling with partial least squares (PLS) estimation, we test the relations between strategic profile, structure of artefacts of management control, and innovation processes. 
Besides this introduction, this paper is structured as follows: first, the literature review, the development of hypotheses and the presentation of the theoretical model. Next, the study's methodological issues are presented, followed by the analysis and discussion of the research results and its conclusions.

\section{LITERATURE REVIEW, HYPOTHESES AND THEORETICAL MODEL}

The development of the theoretical model addressed in this study considers the following elements: innovation, organisations' strategic profile, management control instruments, and the theoretical research model itself.

\subsection{INNOVATION}

The term innovation has been used for different purposes in the business environment, with broader or more restricted innovations. It is characterised as change that enhances evolution or involution, in any of the competitive dimensions, aiming to extend an organisation's life (FREEMAN, 2004; MAGALHÃES, 2007). Rogers' (1995) approach can be highlighted because it specifies innovation as an idea, practice or object that an individual or adoption unit perceives as new and this view will be used in this paper.

According to Rogers (1995), as important as innovation is the dissemination of the innovation, which is the process through which change occurs in the structure, in function of the social system. This relationship is relevant because not all innovations will be absorbed by the organisations.

Innovation consists of processes through which novelties and changes are introduced in the company, whether in products, manufacturing or administrative processes, in the organisational structure or in actual operations (DAFT, 1978; DAMANPOUR; EVAN, 1984; BISBE; OTLEY, 2004). It is related with the required knowledge level and influences the intensity of the change and novelty.

Innovations can be incremental, corresponding to small changes in existing products, processes and technologies and radical, revolutionary innovation, which incorporates new technological platforms and new products and processes (ARCAND et al., 2010; KOBERG; DETINENNE; HEPPARD, 2003). If the organization adopts both the incremental and the radical innovation approach, the core competence should be destroyed and rebuilt what could create a life cycle for the innovation process (LU; CHEN, 2010; TUSHMAN; ANDERSON, 1986 ). On the other hand, using the two approaches, it is possible that it will benefit 
incremental but not the radical due to it creates a conflictive expectation on employees (UN, 2010).

It is presumed that the one that adopts the incremental perspective has in mind that the worst organization learn from the better enterprises and the one that adopts the radical approach "emphasize to jump the existing frame out, however, innovation with the limited resources (fund, resources and ability)" (LU; CHEN, 2010, p.8197). Djellal \& Gallouj (2007) mentioned that the incremental has as motivation the efficiency improvement and cost reduction. Specifically talking about innovation in process, the labour-saving and the capital deeping are the main focus and specially focused in the back office; in the case that the radical innovation emerges, the front office is the focus and quality improvement is frequently the main point (DJELLAL; GALLOUJ, 2007) and the more radical the innovation is, the delivery of new services is offered.

The treatment of the two approaches is complex and requires defined strategy and structure to align and accomplish the goals (ETTLIE; BRIDGES; O’ KEEFE, 1984). Several issues must be considered in the two approaches: cost (ETTLIE et al., 1984), risk, technology, and continuity of the organization (ALI, 2000; UN, 2010). As radical innovation requires more new knowledge them incremental, the need of psychological safety is higher in order to explore new ideas; on the other hand, incremental innovation requires more capability of integration of internal capability (UN, 2010). From any perspective, the dilemma of incremental and/or radical innovation perspective is not easily solved (VARADARAJAN, 2009).

Innovation can be enhanced simultaneously by encouragement factors and factors that determine the organisation's skill and capacity to address change (NARANJO-GIL et al., 2009). In this sense, formal mechanisms can structure the innovation process, providing support and encouraging its development.

\subsection{ORGANIZATIONS' STRATEGIC PROFILE}

If innovation derives from and strongly depends on the general strategy employed by the organisation, it is fundamental that the manner in which this strategic direction occurs is established in the model. In other words, innovation is related to some strategic definition process, whether formal or not. Gosselin (1997) argues that the organisational strategy and, more specifically, the four strategic types proposed by Miles and Snow (2003) play a key role in the innovation process, as the strategy a given business unit adopts directs the need for innovation. Kober, $\mathrm{Ng}$ and Paul (2007) examined the interrelationship between management 
control system and strategy and their findings indicated changes in strategy and in the usage of management control mechanisms over the time periods studied.

Organisational actions related to strategic concepts exist even before a strategy is developed as part of a firm's actions in response to issues (HANSEN; MOURITSEN, 2005). Strategy is one of the operations of organisational actions. Therefore, the profile's characteristic traits are relevant for understanding the organisation's priorities, as, in line with Ferreira, Moulang and Hendro (2010), an organisation's business strategy can influence its use of management control systems. Therefore, Miles and Snow's (2003) approach was chosen to depict the relationship between strategic elements and management control instruments. This well-known approach is used in strategy research (MACINTOSH, 1995; SIMONS, 1995) and in studies on innovation (NARANJO-GIL et al., 2009) and management control (ABERNETHY; BROWNELL, 1999; ITTNER; LARCKER, 2001). This approach identifies possible types of strategies based on the integration of three elements: their definitions, including its mission and values, their basic strategies and the functional strategies of the organisation in general. The typology identifies four types of organisations: defender, prospector, analyser and reactor (MILES; SNOW, 2003).

Defender organisations are those with narrow product-market domains, with senior executives who are specialised in their activity areas and that do not usually look for new opportunities beyond their domain. With regard to basic strategies, defender organisations are aggressive in terms of maintaining their market segment, ignore development beyond their domains, have a high penetration level in the current market, and generally grow cautiously and incrementally.

One may argue that defender organisations have well-defined, stable strategies and frequently a mature domain, aiming for a high level of profitability through the search for alternatives to optimise internal processes, reducing costs and expenses (MACINTOSH; QUATTRONE, 2010). Laforet (2008), in her research concluded that the defenders were relatively smaller than the others profiles. Performance comparisons with the past are characteristic of this profile and the analyses of variations between budgeted and actual flow across all organisational levels.

Because defender companies emphasise coalitions in production and financial areas, the controller stands out, which permits the assertion that the viewpoint of control and the predominance of instruments is predominant (MILES; SNOW, 2003). Consequently, a management control structure that is very rich in planning and control instruments can be 
expected, mainly aimed at cost control, given that the organisation is expected to act in a less uncertain environment, in a focused way and, in many cases, optimising the scale and thus costs (ITTNER; LARCKER, 2001). It means that the focus of the mechanisms drives more to control and guarantee the efficiency than to provide conditions to innovation (HYVÖNEN, 2007).

Prospectors are organisations that: continuously seek opportunities in the market, regularly experience potential responses to new market opportunities that are beyond their main focus and create changes and uncertainties to which competitors must respond. With regard to basic strategies, the domains of these organisations are large and develop continuously, they monitor a wide range of environmental conditions, trends and events, they create changes in their segments, and they grow primarily through entering new markets and creating new products.

Their characteristics and behaviour emphases the entrepreneurs perspectives of the organization (MORGAN; STRONG, 2003) and will be reflected in the management control structure, which is a dual structure: less based on instruments and featuring a greater demand for interaction among people to capture, filter and use information in a more uncertain environment. General idea is that they act based on the incomplete information and await feedback from the market and other elements of environment (MILES; SNOW, 2003). Therefore, managers' self-motivation and competence are crucial for the model's selfmaintenance.

These organisations' main focus is change, which they use to their own benefit against competitors. In the choice between efficiency and effectiveness, the latter is preferred. Under these conditions, marketing and product and market development executives grant the organisation its most relevant directions without necessarily valuing controls and the financial charge approach (MILES; SNOW, 2003). Abernethy and Brownell (1999) found that this kind of organization uses budget interactively with focus in dialogue, communication and learning. Similar finds were mentioned by Hyvönen (2007) and Simons (1987).

These organisations demand planning instruments more superficial than those defender organisations use, as the environment's level of uncertainty and multiplicity does not provide for the same stability demanded by a more formalised and structured model.

Analyser organisations are those that: operate in two types of domains, one stable and the other frequently changing, in stable areas, work according to routine and efficiently and 
use formalised structures and processes, and in more turbulent areas, have their senior executives pay close attention to competitors with a focus on new ideas and rapidly position themselves in the areas they consider most promising.

These organisations' basic strategies are as follows: stable and changing product and market mix, successful imitation through a strong marketing approach, eagerness for change, growth through market penetration, and growth through product and market developments.

Their characteristics and behaviour have a hybrid approach, it displays characteristics of the defender and prospector profiles and, depending on the predominance, tends towards one or the other type (MACINTOSH; QUATTRONE, 2010). This profile doesn't have a unified planning process but it is required a process that is both intensive and comprehensive (MILES; SNOW, 2003).

Consequently, analyser organisations adopt a dual perspective, which participants may question. This approach is reflected in a dual management control structure, that must be capable of granting conditions to monitor the efficiency perspective in stable environments and, at the same time, effectiveness in more volatile environments.

As consequence of the description of different profiles by literature, the hypothesis 1 is structured considering that the existence of the management instruments depends on the specificity of the typology:

$\mathrm{H}_{1}$ : the more adherence to defender or prospector or analyser strategic profile higher usage of management control instrument structure.

Reactor organisations are those in which senior executives perceive the change and uncertainty in the activity environment, do not manage to react efficiently, and do not have a consistent strategy and structure and make adjustments in reaction without much proactive strength. The main point in this profile is that does not have a consistency in the strategy, consequently the same with the management control features (FERREIRA; OTLEY, 2009).

The conclusion about this profile and reason for not be treated is that it is unsustainable (CADEZ; GUILDING, 2008). The decision process predominantly occurs in secret, and communication frequently becomes distorted. Actually they there is a lack of planning process (MAVONDO, 2000). As mentioned by Miles and Snow, (2003), there is a lack of a set of consistent response mechanisms that can put into effect. In practical terms, they do not have or do not preponderantly use instruments such as strategic planning or planning and budget control. Consequently, in addition to losing the utility of active 
management, the organisation loses the opportunity to learn and gain maturity. Financial managers are treated as bookkeepers and are not expected to adopt proactive attitudes towards business and strategy (MACINTOSH; QUATTRONE, 2010).

Naranjo-Gil et al. (2009) consider that the organisation's strategy should precede the design of the Management Accounting System, which in turn permits associating a given organisational strategy and design with value creation objectives (ITTNER; LARCKER, 2001). After deciding on the value drivers, agents can develop and later assess plans. In these conditions, it is relevant to understand the change process in the development of innovation. In addition, Ferreira et al. (2010) argue that strategy is a determinant element of an organisation's management control system. If the organization doesn't have a defined strategy and planning process, it is expected that the instruments will not be available or in use.

Except for the reactor approach, in which a poor profile can be expected in terms of the management control structure, it is to be expected that other profiles have mechanisms at their disposal for strategy development and control. Therefore, based on the above and in function of the specified approach, the research hypothesis 2 was established:

$\mathrm{H}_{2}$ : the more adherence to reactor strategic profile lower usage of management control instrument structure.

\subsection{MANAGEMENT CONTROL INSTRUMENTS}

Control is the process of measuring and assessing the actual performance of each organisational component and developing corrective activities to continue to pursue the planned goals and, when necessary, to monitor efficient compliance with objectives, targets, policies and standards (WELSCH et al., 1988). The control system (diagnosis) should allow the organisation to reach its goals without too much effort, based on management by exception (SIMONS, 1995). From the perspective of the control system, individuals are autonomous and are responsible for results but can choose how to reach them. Therefore, it is fundamental for targets to exist, which help to ensure that managers are heading in the right direction to reach their goals.

In this paper management control is treated as the process to guide the organisation to viable activity standards in a changing environment (BERRY et al., 2005). According to Simons (1995), the management control system should provide support to: reduce the risk or temptation or pressure, being used selectively to reinforce the organisation's rules of the "game" because it formalises the goals that should be targeted and later assessed; provide 
focus and resources for individual searches for opportunities; stimulate innovation, inspiring and motivating executives to seek new opportunities and reduce the fear of challenging the status quo, opening up debate and dialogue and keeping pace with organisation learning.

Merchant and Van der Stede (2007) present organisations' planning systems as serving different goals: organisational planning, activity coordination, facilitate the top administration's general view and executives' motivation. To achieve these goals, it is fundamental for the organisation to have instruments that contribute, support and make their accomplishment feasible. Accordingly, Merchant and Van der Stede (2007) present these instruments as existing in cycles. According to the authors, there are formal and sequential distinctions with the planning and control process, which are: the strategic planning cycle; the capital budget cycle and the budget cycle. In this research, capital budget is part of strategic planning. The concept of cycles adopts the perspective that these instruments should be used in a given sequence and hierarchy, influencing the management model. Once defined, the organisation's strategies demand implementation instruments in the long and short terms. Based on the cycles, in addition to identifying the most relevant instruments, other complementary instruments arise, which enable the process to be improved. These are the BSC and rolling forecast, for example, which complement the integration with strategic planning, budgets and budget control.

In the past, the relationship between formal controls and innovation was regarded as somewhat negative (DAMANPOUR, 1991; GERWIN; KOLODNY, 1992; VERONA, 1999; ABERNETHY; BROWNELL, 1999), which has since been contested (BISBE; OTLEY, 2004; CHENHALL et al., 2011). Formal controls may also entail both positive and negative influences, depending on the environment (BOULIANNE, 2007). The reason why management control used to be perceived as a barrier to innovation is that it was associated with the organisation's mechanistic system (BURNS; STALKER, 1961). It also shows sensitive evolution in the sense that a separation was perceived between management control, strategic planning and strategy (HANSEN; MOURITSEN, 2005), which is currently perceived in a coordinated and inter-related manner.

Attempting to characterise management control systems of Brazilian innovative companies, Oyadomari, Cardoso Silva, and Perez (2010) found that the use of controls neither limits nor complicates innovation. These authors' study findings suggest that the management control system takes shape as an instrument to monitor innovation, permitting its feasibility and practice. Therefore, considering that the instruments of the management 
control system constitute ideologies (MACINTOSH; QUATTRONE, 2010), they are used to enhance efficiency, which fundamentally influences success relative to competitors. Instead of being formal and static, management control should be dynamic, as a part of the social system, granting autonomous judgment, with a positive effect on the innovation process (DAVILA, 2005). Revellino and Mouritsen (2009) indicate that the development of controls helps with the form of the innovation, influencing people regarding what to do and what not to do (EMMANUEL et al., 1990). In addition, Chenhall et al. (2011) conclude that the combination of instruments permits finding a profile in which they exist and are used in a flexible and adjusted way. Macintosh and Quattrone (2010) indicate that comparative logic should mark the success of innovation projects from a competitive standpoint. Without this approach, innovation becomes a mere internal reference without perceiving means of capturing market success. One possible way to indicate the impact of the instruments is the intensity of the innovation developed in the organization. It can be measured by the incremental (relative low intensity) and radical (relative higher intensity) innovation. Therefore, the hypotheses were developed:

$\mathrm{H}_{3}$ : the more the intensity of usage of the management control instruments higher is the intensity of incremental innovation.

$\mathrm{H}_{4}$ : the more the intensity of usage of the management control instruments higher is the intensity of radical innovation.

\subsection{THEORETICAL RESEARCH MODEL}

On the whole, the theoretical research model intends to structure and analyse different constructs found in the literature, aiming to address the correlation between the strategic profile and management control instruments. Therefore, the starting point of the model is the strategic profile, which affects the organisation's management control instrument structure.

The profiles present different demands for instruments. This distinction is not very clear, in which the profile with the highest adherence level to the usage of instruments is the defender profile, whereas the least adherent is the reactor (ITTNER; LARCKER, 2001; MACINTOSH; QUATTRONE, 2010). The model considers the predominant factors of each strategic type, individually associated with the set of variables to capture the impact of the types (defender, prospector, analyser and reactor). Analysing each profile's set of factors associated with the set of instruments is the sequence of this research. Because instruments influence the innovation process (BISBE; OTLEY, 2004; AX; BJORNENAK, 2005; BISBE; MALAGUEÑO, 2009), this impact is relevant; one of the Simons's (1995) perspectives notes 
that the set of management control instruments, related with the diagnostic system, enables the implementation and monitoring of innovation.

Figure 1 summarises the set of constructs that the theoretical model addresses and subjects to empirical testing, showing the relations among the different constructs and the hypotheses developed.

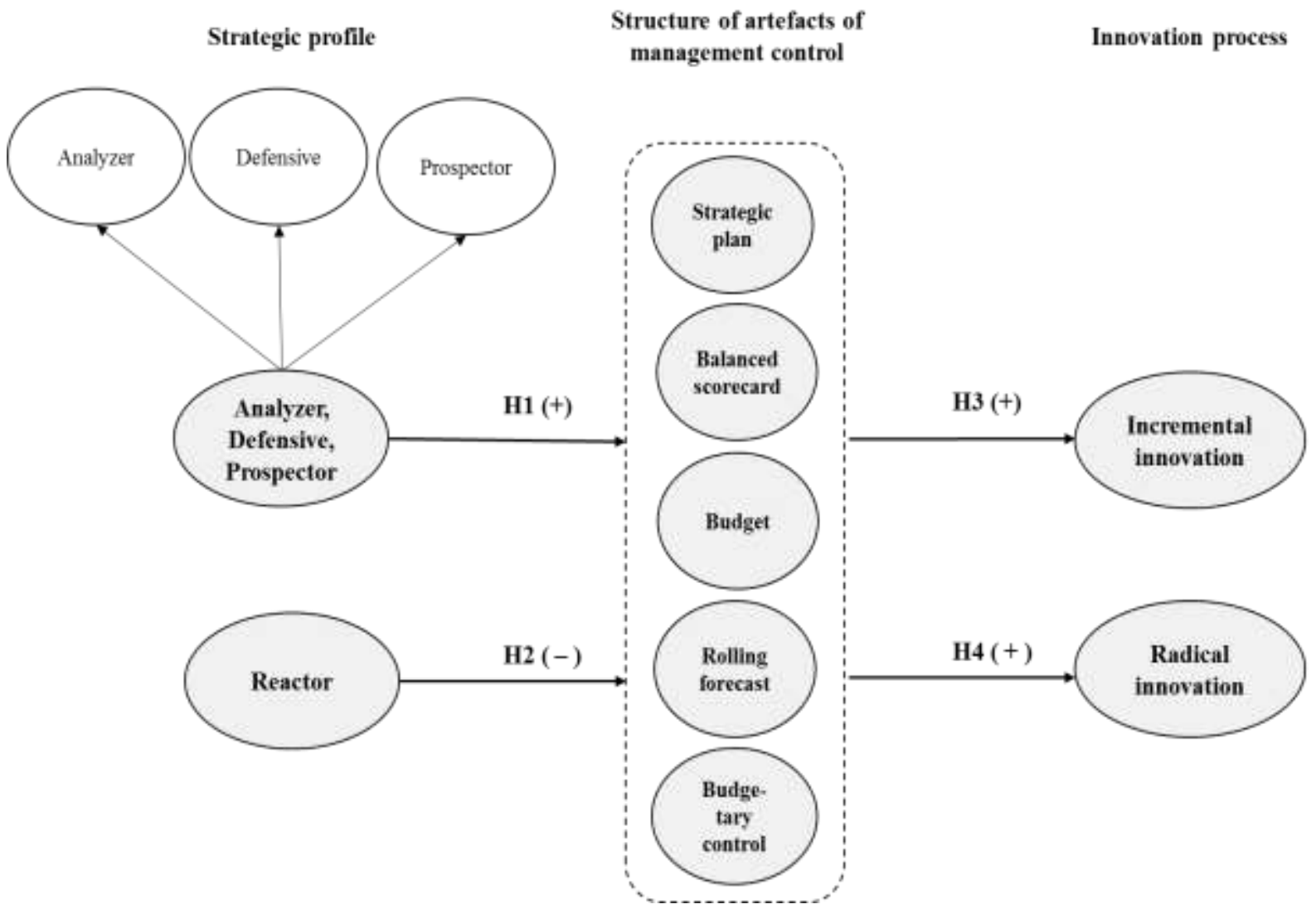

Figure 1 - Theoretical research model

Note 1: We draw just one arrow for each hypothesis just to keep the picture simple, but we have five relations for each arrow, one for each artefact of management control. In the results, we discriminated them as $\mathrm{H} 1 \mathrm{a}$ to $\mathrm{H} 1 \mathrm{e}, \mathrm{H} 2 \mathrm{a}$ to $\mathrm{H} 2 \mathrm{e}, \mathrm{H} 3 \mathrm{a}$ to $\mathrm{H} 3 \mathrm{e}$, and $\mathrm{H} 4 \mathrm{a}$ to $\mathrm{H} 4 \mathrm{e}$.

Note 2: All ellipses are first order latent variable, but analyser/defensive/prospector, that is second order latent variable.

\section{METHODOLOGICAL ISSUES}

To map the role played by management control instruments in the innovation management model in Brazilian organisations, a survey was developed based on a structured questionnaire. Therefore, the study population included large-sized companies, both publicly traded and closed, Brazilian or not, public or private, provided that they operated in Brazil. The database for the identification of the population and sample treatment was derived from the database used by the annual magazine Melhores \& Maiores, of 2010 and field research 
The Structure of Artefacts of Management Control in the Innovation Process:

Does Exist Association with the Strategic Profile?

developed in 2011. The database contains approximately 2,300 companies in a group of different sectors, as displayed in Table 1.

Table 1 - Population Segments per Sector

\begin{tabular}{l|c}
\hline Sector & $\mathbf{n}$ \\
\hline Services & 18 \\
Energy & 10 \\
Chemical and & 10 \\
Petrochemical & 8 \\
Civil construction & 8 \\
Transportation & 7 \\
Bens de Consumo & 6 \\
Wholesale & 6 \\
Agrobusiness & 5 \\
Automobile & 5 \\
Mining & 5 \\
Paper and cellulose & 4 \\
Electric \& electronic & 4 \\
Machinery \& equipment & 3 \\
Digital industry & 3 \\
Siderurgy \& metalurgy & 3 \\
Telecommunication & 3 \\
Textile & 3 \\
Retail & 2 \\
Communication & 1 \\
Farmaceutical & 7 \\
Several others & \\
& \\
\hline \multicolumn{1}{c}{ Total } & $\mathbf{1 2 1}$ \\
\hline
\end{tabular}

\begin{tabular}{l|c}
\hline Revenues distribuition (millions R\$) & $\mathbf{n}$ \\
\hline Up to 50 & 2 \\
From 51 up to 100 & 12 \\
From 101 up to 250 & 36 \\
From 251 up to 500 & 26 \\
From 501 up to 1.000 & 13 \\
From 1.001 up to 3.000 & 17 \\
Higher than 3.000 & 9 \\
Missing & 6 \\
\hline \multicolumn{2}{|c}{} \\
\hline Equity control & $\mathbf{n}$ \\
\hline Brasilian & 84 \\
Governmental & 9 \\
German & 5 \\
American & 5 \\
English & 4 \\
Dutch & 3 \\
Japanese & 3 \\
Swiss & 2 \\
Others & 6 \\
\hline \multicolumn{2}{|c}{ Total } \\
\hline Stocks negotiated in 2009 & $\mathbf{n}$ \\
\hline No & 111 \\
Yes & 8 \\
Pending & $\mathbf{1 2 1}$ \\
\hline \multicolumn{2}{|l}{} \\
\hline
\end{tabular}

Note: Values in 31/12/2009:

$\mathrm{US} \$ 1,00=\mathrm{R} \$ 1.7412(\mathrm{U} \$ 0.5743 / \mathrm{R} \$)$

$€ 1,00=\mathrm{R} \$ 2.5073(€ 0.3988 / \mathrm{R} \$)$

Source: PORTAL BRASIL NET (2009).

According to Malerba (2005), innovation displays extreme distinctions among the sectors in terms of characteristics, sources, actors involved, process borders and in terms of the innovation activities' organization itself. In this study, however, the sector variable did not reveal a discriminant role, both due to the number of companies used and their considerable distribution across different sectors.

The questionnaire was developed according to the references used in the body of text (content validity). Table 2 identifies items, scale and factor loadings. Referring to scales, there were two different scales: a five-point Likert for all the questions except the ones that it was required to capture different status of existence or implementation. In this case it was considered the ordinal scale. 
Table 2 - Convergent Validity and Content Validity

\begin{tabular}{|c|c|c|c|c|}
\hline $\begin{array}{l}\text { Latent } \\
\text { Variable }\end{array}$ & Statement & Scale & References & $\begin{array}{l}\text { Factor } \\
\text { loading }\end{array}$ \\
\hline \multirow{4}{*}{ Analyser } & $\begin{array}{l}\text { growth normally occurs through product development and } \\
\text { marketing }\end{array}$ & \multirow{13}{*}{ A } & \multirow{13}{*}{$\begin{array}{l}\text { Miles and } \\
\text { Snow } \\
(1978)\end{array}$} & 0.725 \\
\hline & $\begin{array}{l}\text { provides stability in the product and market max and changes in } \\
\text { others }\end{array}$ & & & 0.617 \\
\hline & hungry for change & & & 0.729 \\
\hline & growth occurs through market penetration & & & 0.641 \\
\hline \multirow[t]{2}{*}{ Defender } & $\begin{array}{l}\text { aggressive in remaining within the organisation's market } \\
\text { segment }\end{array}$ & & & 0.820 \\
\hline & organisation has deep penetration in the current market & & & 0.818 \\
\hline \multirow{4}{*}{$\begin{array}{c}\text { Prospecto } \\
\text { r }\end{array}$} & $\begin{array}{l}\text { regularly pursues new potential market opportunities outside the } \\
\text { organisation's main focus }\end{array}$ & & & 0.743 \\
\hline & grows primarily in new markets and new products & & & 0.654 \\
\hline & $\begin{array}{l}\text { continually researches market opportunities, including those } \\
\text { outside the organisation's domain focus }\end{array}$ & & & 0.812 \\
\hline & $\begin{array}{l}\text { creative changes and uncertainties to which competitors must } \\
\text { respond }\end{array}$ & & & 0.746 \\
\hline \multirow{3}{*}{ Reactor } & $\begin{array}{l}\text { managers articulate a viable strategy, but do not have the } \\
\text { technology, structure and processes adequately related }\end{array}$ & & & 0.710 \\
\hline & $\begin{array}{l}\text { managers adhere to a particular strategy/structure that is not } \\
\text { relevant to the desired environment }\end{array}$ & & & 0.808 \\
\hline & managers fail to articulate a viable organisational strategy & & & 0.904 \\
\hline \multirow{4}{*}{ BSC } & $\begin{array}{l}\text { Balanced Scorecard (provide the setting closest to the reality of } \\
\text { the organisation where you work) }\end{array}$ & $\mathrm{C}$ & \multirow{4}{*}{$\begin{array}{c}\text { Kaplan and } \\
\text { Norton } \\
(1996)\end{array}$} & 0.839 \\
\hline & $\begin{array}{l}\text { The Balanced Scorecard is used as an aligning strategy in } \\
\text { assembling the budget }\end{array}$ & \multirow{3}{*}{ A } & & 0.921 \\
\hline & $\begin{array}{l}\text { The Balanced Scorecard is used as a strategic management } \\
\text { instrument to plan and track results }\end{array}$ & & & 0.914 \\
\hline & $\begin{array}{l}\text { The Balanced Scorecard is used to track the performance of the } \\
\text { company in a way that is not linked to strategic planning }\end{array}$ & & & 0.772 \\
\hline $\begin{array}{l}\text { Budget } \\
\text { control }\end{array}$ & $\begin{array}{l}\text { There exists budgetary control in the company (report and } \\
\text { discussion of expected outcomes planned and achieved) }\end{array}$ & \multirow{3}{*}{ B } & \multirow{8}{*}{$\begin{array}{c}\text { Merchant } \\
\text { and Van der } \\
\text { Stede } \\
(2007)\end{array}$} & 1.000 \\
\hline \multirow{3}{*}{ Budgeting } & Budgeting exists in the company's annual budget & & & 0.886 \\
\hline & the budget is aligned to strategic planning and follows it & & & 0.848 \\
\hline & $\begin{array}{l}\text { There exists an annual budget (provide the setting closest to the } \\
\text { reality of the organisation where you work) }\end{array}$ & \multirow{3}{*}{$\mathrm{C}$} & & 0.853 \\
\hline \multirow{2}{*}{$\begin{array}{l}\text { Strategic } \\
\text { planning }\end{array}$} & There is formalised strategic planning in business & & & 0.955 \\
\hline & $\begin{array}{l}\text { These exists strategic planning (provide the setting closest to the } \\
\text { reality of the organisation where you work) }\end{array}$ & & & 0.938 \\
\hline \multirow{2}{*}{$\begin{array}{l}\text { Rolling } \\
\text { forecast }\end{array}$} & $\begin{array}{l}\text { there is rolling forecast (projections aimed at providing financial } \\
\text { results) }\end{array}$ & $\mathrm{B}$ & & 0.922 \\
\hline & $\begin{array}{l}\text { rolling forecast (provide the setting closest to the reality of the } \\
\text { organisation where you work) }\end{array}$ & $\mathrm{C}$ & & 0.892 \\
\hline Innovatio & $\begin{array}{l}\text { Incremental: continuous changes (or lack thereof) to improve } \\
\text { what already exists. Examples: improved product, improved }\end{array}$ & A & Arcand et & 1.000 \\
\hline
\end{tabular}




\begin{tabular}{l|l|l|c|c}
\hline $\mathrm{n}$ & process, etc. & \multirow{2}{*}{ al. (2010) } & \\
\cline { 2 - 5 } & $\begin{array}{l}\text { Radical revolutionary changes. Example: product outside the } \\
\text { previous focus of the company, the budget aligned to strategic } \\
\text { planning and follows production substantially different from } \\
\text { your core business, etc. }\end{array}$ & & 1.000 \\
\hline
\end{tabular}

Note 1: All the factor values are significant $(\mathrm{p}<0,01)$ and they were estimated by SmartPLS 2.0.M3 (RINGLE, WENDE, WILL, 2005).

Note 2: Scales: (a) Type A: 5, 4, 3, 2, 1, 0 - totally agree, partly agree, do not agree or disagree, partly disagree, fully disagree, I don't know; (b) Type B: 4, 3, 2, 1, 0 - yes, sufficiently consolidated; yes, but still insipient in usage; in the implementation process; no, doesn't exist in the organisation; I don't know; (c) Type C: 3, 2, 1, 0fully formalised in the organisation; formalised in part in some areas; not formalised in the organisation, but there is a similar instrument; doesn't exist.

The data collection questionnaire was chosen due to its adequacy in terms of its range and objectivity. The questionnaire was sent to the companies electronically. The data collection lasted three months (June till September 2011) and resulted in 121 fully completed questionnaires. Most respondents (57.85\%) served on the board, management or as accountants.

For statistical analysis of the survey data, the analysis phases were as follows: descriptive statistics, with means, standard deviation, minima and maxima; hypotheses tests, structured to grant consistency to the analysis and conclusions; confirmatory factor analysis to assess the measurement model of the latent variables: reliability and validity tests were conducted by composite reliability and average variance extracted.

Structural equation modeling with PLS estimation (Partial Least Squares Path Modelling) was preferred over LISREL, AMOS or EQS because the first is more suitable in cases where we have: small sample size (lower than 200) and non-normality (Hair Jr. et al. 2014, p.19).

\section{RESULTS AND DISCUSSION}

First the results of the measurement model (convergent validity, discriminant validity and reliability) are presented, followed by an analysis of correlations among the constructs and structural model (path coefficients and $\mathrm{R}^{2}$ ).

Convergent validity was assessed through the average variance extracted (AVE), observing that all latent variables exceeded the recommended value of 0.5 (HAIR JR. et al., 2014), except for the latent variables of the analyser strategic type and innovation intensity, which scored 0.46. Composite reliability (CR) exceeded 0.7 (HAIR JR. et al., 2014) and thus the measurement model was considered adequate (Table 3 ). 
Table 3 - Convergent Validity and Reliability

\begin{tabular}{|l|c|c|}
\hline \multicolumn{1}{c|}{ Latent Variable } & $\begin{array}{c}\text { Average Variance } \\
\text { Extracted }\end{array}$ & $\begin{array}{c}\text { Composite } \\
\text { Reliability }\end{array}$ \\
\hline Analyser & 0.463 & 0.774 \\
Defender & 0.671 & 0.803 \\
\hline Prospector & 0.548 & 0.829 \\
Reactor & 0.659 & 0.851 \\
BSC & 0.745 & 0.921 \\
Budget Control (BC) & 1.000 & 1.000 \\
Budget (B) & 0.744 & 0.897 \\
Strategic Planning (SP) & 0.895 & 0.945 \\
Rolling Forecast (RF) & 0.822 & 0.903 \\
Innovation & 0.468 & 0.777 \\
\hline Analyser, defender, prospector & & \\
(2 & & 0.743 \\
\hline
\end{tabular}

Note: In Table 4 we see that analyzer, defender and prospector profiles are correlated (.58 to .70), then they are grouped as indicators of a second order latent variable, using the repeated indicators approach (HAIR Jr. et al., 2014, p.229-232).

The discriminant validity assessment at the level of the latent variables is presented in Table 4, we observe that the correlations among the latent variables are lower than the square root of the extracted mean variance (values on the diagonal of the matrix), except for the correlation between the latent variable of the analyser and prospector strategic profiles. Nevertheless, the diattenuated correlation equalled 0.88 , indicating that discriminant validity continues to exist in this case, according to the criterion proposed by Netemeyer, Bearden and Sharma (2003). Beside this, the latent variable of the analyser and prospector strategic profiles were used as indicators of the same $2^{\text {nd }}$ order LV, for this reason, the high correlation between them was not a problem for future analysis.

Table 4 - Matrix of Correlations between first order latent variables

\begin{tabular}{|c|c|c|c|c|c|c|c|c|c|c|c|}
\hline Variable & 1 & 2 & 3 & 4 & 5 & 6 & 7 & 8 & 9 & 10 & 11 \\
\hline 1 Analyser & 0.680 & & & & & & & & & & \\
\hline 2 Defender & 0.582 & 0.819 & & & & & & & & & \\
\hline 3 Prospector (d) & 0.704 & 0.590 & 0.741 & & & & & & & & \\
\hline 4 Reactor & -0.091 & -0.124 & 0.051 & 0.811 & & & & & & & \\
\hline $5 \mathrm{BSC}$ & 0.180 & 0.257 & 0.266 & -0.086 & 0.864 & & & & & & \\
\hline 6 Budget Control & 0.086 & 0.216 & 0.066 & -0.282 & 0.145 & 1.000 & & & & & \\
\hline 7 Budget & 0.126 & 0.158 & 0.123 & -0.258 & 0.234 & 0.642 & 0.862 & & & & \\
\hline 8 Strategic Plan & 0.226 & 0.231 & 0.173 & -0.108 & 0.257 & 0.432 & 0.632 & 0.946 & & & \\
\hline 9 Rolling Forecast & 0.253 & 0.411 & 0.269 & -0.108 & 0.407 & 0.429 & 0.474 & 0.360 & 0.907 & & \\
\hline 10 Inc. Innov. & 0.254 & 0.248 & 0.192 & -0.154 & 0.156 & 0.095 & 0.082 & 0.234 & 0.039 & 1.000 & \\
\hline 11 Radical Innov. & 0.276 & 0.144 & 0.192 & -0.075 & 0.295 & 0.068 & 0.209 & 0.258 & 0.102 & 0.153 & 1.000 \\
\hline
\end{tabular}




\begin{tabular}{lccccccccccc}
\hline AVE & 0.462 & 0.671 & 0.549 & 0.658 & 0.746 & 1.000 & 0.744 & 0.895 & 0.823 & 1.000 & 1.000 \\
CR & 0.774 & 0.803 & 0.829 & 0.851 & 0.921 & 1.000 & 0.897 & 0.945 & 0.903 & 1.000 & 1.000 \\
\hline Mean & 3.7 & 4.0 & 3.3 & 2.3 & 1.9 & 3.7 & 3.2 & 2.7 & 2.4 & 4.6 & 3.2 \\
\hline Median & 3.8 & 4.0 & 3.5 & 2.1 & 2.1 & 4.0 & 3.3 & 3.0 & 2.5 & 5.0 & 4.0 \\
\hline Standard deviation & 0,82 & 0,96 & 0,98 & 1,09 & 1,38 & 0,52 & 0,65 & 0,93 & 1,02 & 0,78 & 1,61 \\
\hline Variation coefficient & $22 \%$ & $24 \%$ & $30 \%$ & $48 \%$ & $71 \%$ & $14 \%$ & $20 \%$ & $34 \%$ & $42 \%$ & $17 \%$ & $51 \%$ \\
\hline Scale & 1 to 5 & 1 to 5 & 1 to 5 & 1 to 5 & (a) & 1 to 4 & 1 to 4 & (b) & (c) & 1 to 5 & 1 to 5 \\
\hline
\end{tabular}

Notes: Values in bold on the diagonal of the matrix are the square roots of the average variance extracted. Correlation higher than $|0.17|$ are significant at $5 \%$ and higher than $|0.23|$ are significant at $1 \%$.

(a): One indicator from 0 to 3 and three from 0 to 5. See note 2 of Table 2.

(b): One indicator from 0 to 3 . See note 2 of Table 2.

(c): One indicator from 0 to 3 and another from 0 to 4 . See note 2 of Table 2.

(d): The diattenuated correlation between analyser and prospector strategic profiles was 0.88 , indicating that discriminant validity continues to exist in this case, according to the criterion proposed by Netemeyer, Bearden and Sharma (2003).

Based on the results in Tables 2, 3 and 4, it is concluded that the proposed measurement model displays adequate convergent validity, discriminant validity and reliability. The significance level was defined as $1 \%$ and $5 \%$ as described in Table 4 and 5.

\subsection{STRATEGIC PROFILE AND MANAGEMENT CONTROL INSTRUMENTS}

Table 5 clarifies the findings regarding the defender, prospector and analyser strategic profiles, which consist of the existence of the instruments under analysis e.g., strategic planning, BSC, budget and rolling forecast.

This way, the hypotheses 1 and 2 were partly confirmed and what is relevant is that each profile has its own combination of instruments (see table 5).

Table 5 - Results of the Structural Model

\begin{tabular}{lcccccc}
\hline \multicolumn{1}{c}{ Hypotheses) Structural relations } & & $\begin{array}{c}\text { Path } \\
\text { coefficient }\end{array}$ & $\begin{array}{c}\text { Standard } \\
\text { Error }\end{array}$ & t-value & p-value & $\mathbf{R}^{\mathbf{2}}$ \\
\hline H1a) An_Def_Prosp -> Strategic Plan & (a) & 0.227 & 0.079 & 2.86 & $\mathbf{0 . 0 0 4 3}$ & $6.2 \%$ \\
H2a) Reactor -> Strategic Plan & & -0.092 & 0.094 & 0.97 & 0.3301 & \\
H1b) An_Def_Prosp -> BSC & (a) & 0.258 & 0.087 & 2.97 & $\mathbf{0 . 0 0 3 1}$ & $7.0 \%$ \\
H2b) Reactor -> BSC & & -0.051 & 0.116 & 0.44 & 0.6589 & \\
H1c) An_Def_Prosp -> Budget & & 0.165 & 0.093 & 1.79 & 0.0746 & $9.1 \%$ \\
H2c) Reactor -> Budget & (a) & -0.245 & 0.104 & 2.37 & $\mathbf{0 . 0 1 8 0}$ & $12.2 \%$ \\
H1d) An_Def_Prosp -> Rolling forecast & (a) & 0.333 & 0.084 & 3.96 & $\mathbf{0 . 0 0 0 1}$ & \\
H2d) Reactor -> Rolling forecast & & -0.092 & 0.091 & 1.01 & 0.3133 \\
H1e) An_Def_Prosp -> Budget control & & 0.112 & 0.065 & 1.73 & 0.0846 & $9.0 \%$ \\
H2e) Reactor -> Budget control & (a) & -0.273 & 0.094 & 2.91 & $\mathbf{0 . 0 0 3 7}$ \\
H3a) Strategic Plan -> Incremental & (a) & 0.291 & 0.131 & 2.23 & $\mathbf{0 . 0 2 6 0}$ \\
H3b) BSC -> Incremental & & 0.132 & 0.083 & 1.59 & 0.1120 & $7.9 \%$ \\
H3c) Budget -> Incremental & & -0.125 & 0.136 & 0.92 & 0.3555 \\
H3d) Rolling forecast -> Incremental & & -0.085 & 0.122 & 0.70 & 0.4867
\end{tabular}




$\begin{array}{llllll}\text { H3e) Budget control -> Incremental } & 0.069 & 0.099 & 0.69 & 0.4883 \\ \text { H4a) Strategic Plan -> Radical } & 0.158 & 0.137 & 1.15 & 0.2502 \\ \text { H4b) BSC -> Radical } & \text { (a) } & 0.273 & 0.098 & 2.78 & \mathbf{0 . 0 0 5 6} \\ \text { H4c) Budget -> Radical } & 0.183 & 0.189 & 0.97 & 0.3337 & 14.6 \% \\ \text { H4d) Rolling forecast -> Radical } & -0.106 & 0.109 & 0.97 & 0.3320 & \\ \text { H4e) Budget control -> Radical } & -0.101 & 0.126 & 0.80 & 0.4215\end{array}$

Legend: An_Def_Prosp $=$ Analyzer. Prospector and Defender $=2^{\text {nd }}$ order latent variable with repeated indicators approach (HAIR Jr. et al., 2014, p.231).

(a) = Hypothesis supported

As expected, the Analyser/Defender/Prospector profile is the most adherent to the instruments (see table 5), confirming strategic planning (Path Coefficient $=\mathrm{PC}=0.227, \mathrm{p}<$ $.01)$, the $\mathrm{BSC}(\mathrm{PC}=0.258, \mathrm{p}<.01)$ and rolling forecast $(\mathrm{PC}=0.333, \mathrm{p}<.01)$. The strategic planning and BSC are the instruments that should alert the organization to the need of innovation (MILLER; FRIESEN, 1984). This finding is relevant, confirming the existing belief that this is the most structured strategic type in terms of its formalisation of planning and control instruments (MILES; SNOW, 2003).

According to the literature (ITTNER et al., 2003; MACINTOSH; QUATTRONE, 2010), stability is not the strong suit of Prospector Profile; instead, these firms' objective is to change, and their management is oriented more towards managers' actions (MORGAN; STRONG, 2003) than towards the strictness and formalisation of instruments. Because these companies operate in a less stable environment with a focus on change, the BSC is used as a driver of actions through its indicators. The rolling forecast is used because it captures environmental changes from time to time that are incorporated into the organisation's operational planning system less strictly than the budget (SIMONS, 1987). In line with other strategic profiles, the combination of instruments enables a flexible approach, combining the participatory and comprehensive potential presented by the BSC with the ability to transform this information into financial projections through the rolling forecast. The combination of strategic planning, BSC and rolling forecast can provide a flexible combination that can drive the innovation process without a rigid control but a direction.

The analyser/defender/prospector profile, is the hybrid profile and might have wider need then the reactor. The literature considers that, depending on the greater emphasis given to the search for efficiency (cost and expense optimisation) or effectiveness the hybrid model must balance, it is to be expected that the instrument structure display different profiles. Based on the sample data, the combination between long-term elements (strategic planning and the BSC) and a short-term instrument that permits updates and appears to be less strict enhances organisations' planning and control in this profile. Strategic planning, which was 
not emphasised in the prospector profile, provides the long-term view a more complex profile than the previous two demands.

Miles and Snow (2003) specified the absence of a defined strategy in the reactor profile. The lack of focus also impedes the demand for other instruments, which are necessary to construct and then implement a strategy. The negative relationship between the profile characteristics and the use of the budget $(\mathrm{PC}=-0.245, \mathrm{p}<.01)$ and budget control $(\mathrm{PC}$ $=-0.273, \mathrm{p}<.01)$ was confirmed in line with the literature $($ MACINTOSH; QUATTRONE, 2010). The perspective mentioned by Naranjo-Gil et al. (2009) that the organization's strategy should precede the design of Management Accounting System was confirmed in the reactor profile.

Therefore, hypothesis $\mathrm{H}_{1}$ : the more adherence to defender or prospector or analyser strategic profile higher usage of management control instrument structure was confirmed for strategic plan, BSC, and rolling forecast.

Similarly, $\mathrm{H}_{2}$ : the more adherence to reactor strategic profile lower usage of management control instrument structure, was confirmed for budget and budget control.

\subsection{MANAGEMENT CONTROL STRUCTURE AND INNOVATION INTENSITY}

Regarding to level of intensity, there is a linkage between the packages of instruments by each profile and the intensity of innovation (Table 5).

Hypothesis 3 was partially confirmed due to the linkage between incremental innovation and the strategic planning $(\mathrm{PC}=0.291, \mathrm{p}<.01)$. Hypothesis 4 was partly confirmed too for radical innovation and $\mathrm{BSC}(\mathrm{PC}=0.273, \mathrm{p}<.01)$.

The existence of artefacts that provide support for long-term needs, and comparison among different projects, business or divisions and it is important both for radical and incremental innovation. On the other hand, although it was expected that the prospectors have low level of usage of artefacts in radical innovation due to its focus is the people instead of instruments, the artefacts are associated with the incremental innovation.

In the case of defender strategy, although the profile and impact on the intensity is similar to prospectors (the only association between mechanisms and intensity refers to incremental), the reason for the artefacts profile is different: incremental innovation is much more related to this profile due to the continuous pressure to optimise the results than to add new risks to the organization. 
This finding confirms those of the existing literature (NARANJO-GIL et al., 2009). Although the existence of instruments differs among the profiles, the configuration of each is consistent with its characteristics and objectives. Simons (1995) indicates that the existence of instruments aims to stimulate and motivate innovation. Therefore, because the organisation is concerned with enhancing efficiency (defender and analyser types) or effectiveness (prospector and analyser), the instruments make it feasible to structure the implementation process of the innovation. The existence of instruments by itself entails the creation of favourable and assertive discourse, independently of the precision level of the results one would like to obtain for this type of theme.

The strategy is an antecedent of the design of Management Accounting System (NARANJO-GIL et al., 2009) and, in the case of the reactor profile, it has not a clear definition of the strategy. Therefore, mechanisms are not consistent available and the continuum of the results and learning process are not incorporated by the management behaviour. The level of intensity of the innovation is critical to increase the new launching (FRAMBACH; SCHILLEWAERT, 2002) and without mechanisms it is not to plan or to infers assessments. Incremental innovation is associated with the strategic planning that is consistent with the "need" mentioned in the literature that consider critical the integration of capabilities (UN, 2010). The strategic planning can provide this perspective treating the different variables that could optimize the results in a long term. It is expected that the strategy is an antecedent of the strategic planning and it can support the internal alignment (ADAMS et al., 2006). Normally incremental innovation happens thru several different areas of the organization. Coordination of different areas and resources are crucial for this, at least for the planning perspective.

The radical innovation demands a different kind of the mechanism due to it deals with different risk and a more complex tool is required due to the need of more new knowledge them incremental, the need of psychological safety (UN, 2010) for dealing with risk. BSC is expected to work associated with strategic planning and budget and combines the strategic goals, actions and metrics required to achieve the innovation perspectives. This way the mechanisms of BSC can provide conditions of performance assessment for short and long term.

Table 6 shows a summary of the working hypotheses and results.

Table 6 - Summary of Results

\begin{tabular}{|c|c|}
\hline Hypotheses & Results \\
\hline
\end{tabular}




\begin{tabular}{|l|l|l|}
\hline $\begin{array}{l}\mathrm{H}_{1} \text { : the more adherence to defender or prospector or } \\
\text { analyser strategic profile higher usage of management } \\
\text { control instrument structure. }\end{array}$ & $\begin{array}{l}\text { Partially accepted: H1(a) Strategic Plan, H1(b) BSC } \\
\text { and H1(d) Rolling Forecast }\end{array}$ \\
\hline $\begin{array}{l}\text { H2: the more adherence to reactor strategic profile } \\
\text { lower usage of management control instrument } \\
\text { structure. }\end{array}$ & $\begin{array}{l}\text { Partially accepted: H2(c) Budget and H2(e) Budget } \\
\text { Control. }\end{array}$ \\
\hline $\begin{array}{l}\text { H3: the more the intensity of usage of the } \\
\text { management control instruments higher is the } \\
\text { intensity of incremental innovation. }\end{array}$ & Partially accepted: H3(a) Strategic Plan \\
\hline $\begin{array}{l}\text { H4: the more the intensity of usage of the } \\
\text { management control instruments higher is the } \\
\text { intensity of radical innovation. }\end{array}$ & Partially accepted: H4(b) BSC \\
\hline
\end{tabular}

\section{CONCLUSIONS}

Innovation is a vital element of organisations' development and maintenance. It is pursued in different ways as a consequence of the strategic perspective that discerns progress. Its occurrence can be developed in distinct ways and with distinct intensity levels, resulting from the strategic profile chosen. This "choice" can derive from the activity segment, the entity size and the organisation's maturity level. The literature neither takes a precise stand nor clearly indicates organisations' movements across different profiles.

This study empirically tests the role of strategic profiles (defender, prospective, analyser and reactor) and management control instruments in innovation process and makes important contributions to the study of innovation in the management control context. Like addressed by Koberg, Detinenne and Heppard (2003), in our research we distinguish the scope of the innovation (incremental and radical) and tested if radical innovation requires a different management control structure from incremental innovation.

Prior researches suggests that budgets are theoretically linked to innovation (BISBE; OTLEY, 2004) and that greater extent of interactive use of budgets can improve the effectiveness of teams in innovation firms, either directly or indirectly via collective efficacy (CHONG; MOHAMA, in press). However, we do not find support for the predicted relationship between budget and budgeting control and innovation (incremental and radical).

One of the possible elements influencing the strategic profile is the existence or instruments permitting the development of management control in organisations. The set of instruments can be extensive, but this research was limited to the exploration of strategic planning, the BSC, the annual budget, rolling forecast and budget control. Without these instruments, one cannot discuss management control in an organisation, and, based on the interactions of these instruments, one can consider that a strong relationship between 
subordination and sequence exists. In the research sample, this study found a relationship between organisations' strategic profile and existing instruments. This relationship makes intuitive sense, departing from a rational reading, given that the instruments can structure the organisation's strategic desires and its pursuit of defined targets.

This paper contributes to the theme by detailing the management control instruments used by each strategic profile and presenting information about them. On the other hand, the instruments' composition can differ and depend on each organisation's profile. Strategic planning, BSC and rolling forecast are the mechanisms that are common to analyser, prospectors and defenders. The analyser type uses the "kit of tools" in order to balance or track results in the search for efficiency and effectiveness in the same organization. This way it is the profile in which the strategy, the artefacts and innovation intensity are aligned. The prospector type, in turn, focusing on more flexible action changes and being much more concerned with people than with instruments. The defender profile has emphasis in optimization of the results and search for the efficiency. In addition, this research examines innovation not as a single outcome variable, but as a consequence of two important components of literature: strategic profile and structure of artefacts of management control.

About the reactor profile, some questions could be raised due to the only finding is the negative relationship with the budgetary process. As summary the lack of tools is the finding and it could explain the difficulty of direction definition. If the strategy comes first, in relation to Management Accounting System, what could avoid the perception of need and benefit of artefacts?

About the artefacts for incremental innovation the only one identified is the strategic planning that provides integration of the actions. On the other hand, for radical innovation, BSC is the tool identified, that means that the need of mechanisms that could provide psychological safety by strong controls (goals, metrics and actions).

Thinking about migration of one organization from reactor profile to other, what could interfere on the design of mechanisms and provide consistency to management?

\section{REFERENCES}

ABERNETHY, M. A.; BROWNELL, P. The role of budgets in organizations facing strategic change: an exploratory study. Accounting, Organizations and Society, v. 24, n. 3, p. 189204, 1999.

ADAMS, R. BESSANT, J.; PHELPS, R. Innovation management measurement: A review. International Journal of Management Reviews, v.8, n.1, p.21-47, 2006. 
ALI, A. Pioneering Versus Incremental Innovation : Review and Research Propositions. Framework, 46-61. 2000.

ARCAND, S. et al. Sociología de la empresa: del marco histórico a las dinámicas internas. Bogota: Siglo del Hombre, 2010.

AX, C.; BJORNENAK, T. Bundling and diffusion of management accounting innovations?the case of the balanced scorecard in Sweden. Management Accounting Research, v. 16, n. 1, p. 1-20, 2005.

BERRY, A. J.; BROADBENT, J.; OTLEY, D. Management control: theories, issues and performance. 2nd ed. Basingstoke: Palgrave Macmillan, 2005.

BISBE, J.; MALAGUEÑO, R. The Choice of Interactive Control Systems under Different Innovation Management Modes. European Accounting Review, v. 18, n. 2, p. 371-405, 2009.

BISBE, J.; OTLEY, D. The effects of the interactive use of management control systems on product innovation. Accounting, Organizations and Society, v. 29, p. 709-737, 2004.

BOULIANNE, E. Revisiting fit between AIS design and performance with the analyzer strategic-type. International Journal of Accounting Information Systems, v. 8, n. 1, p. 116, 2007.

BURNS, T.; STALKER, G. The management of innovation. London: Tavistock, 1961.

CADEZ, S.; GUILDING, C. An exploratory investigation of an integrated contingency model of strategic management accounting. Accounting, Organizations and Society, v. 33, n. 7-8, p. 836-863, 2008.

CHENHALL, R. H.; KALLUNKI, J.-P.; SILVOLA, H. Exploring the relationships between strategy, innovation, and management control systems: the roles of social networking, organic innovative culture, and formal controls. Journal of Management Accounting Research, v. 23, n. 1, p. 99-128, 2011.

CHONG, K. M.; MAHAMA, H. The impact of interactive and diagnostic uses of budgets on team effectiveness. Management Accounting Research. In press.

DAFT, R. L. A dual-core model of organizational innovation. Academy of Management Journal, v. 21, n. 2, p. 193-210, 1978.

DAMANPOUR, F. Organizational innovation: a meta-analysis of effects of determinants and moderators. Academy of Management Journal, v. 34, n. 3, p. 555-590, 1991.

DAMANPOUR, F.; EVAN, W. M. Organizational innovation and performance: the problem of “organizational lag.”Administrative Science Quarterly, v. 29, n. 3, p. 392-409, 1984.

DAVILA, T. The promise of management control systems for innovation and strategic change. In: C. Chapman (Ed.); Controlling strategy: management, accounting, and performance measurement. New York: Oxford University Press, 2005. p. 37-61. 
DJELLAL, F.; GALLOUJ, F. Innovation and employment effects in services: a review of the literature and an agenda for research. The Service Industries Journal, v. 27, n. 3, p. 193$214,2007$.

EMMANUEL, C.; OTLEY, D.; MERCHANT, K. Accounting for management control. 2. ed. London: Thomson Learning, 1990.

ETTLIE, J. E.; BRIDGES, W. P.;O'KEEFE, R. D. Organization strategy and structural differences for radical versus incremental. Management Science, v. 30, n. 6, p. 682-695, 1984.

FERREIRA, A.; OTLEY, D. The design and use of performance management systems: an extendend framework for analysis. Management Accounting Research. v. 20, n. 4, p. 263 $282,2009$.

FERREIRA, A.; MOULANG, C.; HENDRO, B. Environmental management accounting and innovation: an exploratory analysis. Accounting, Auditing \& Accountability Journal, v. 23, n. 7, p. 920-948, 2010.

FRAMBACH, R. T.; SCHILLEWAERT, N. Organizational innovation adoption: a multilevel framework of determinants and opportunities for future research. Journal of Business Research, v. 55, n. 2, p. 163-176, 2002.

FREEMAN, C. The national system of innovation in historical perspective. Revista Brasileira de Inovação, v. 3, n. 1, p. 15-34, 2004.

GERWIN, D.; KOLODNY, H. Management of advanced manufacturing technology: strategy, organisation and innovation. Chichester: John Wiley \& Sons, 1992.

GOSSELIN, M. The effect of strategy and organizational structure on the adoption and implementation of activity-based costing. Accounting, Organizations and Society, v. 22, n. 2, p. 105-122, 1997.

HANSEN, A.; MOURITSEN, J. Strategies and organizational problems: constructing corporate value and coherence in balanced scorecard process. In: C. S. Chapman (Ed.). Controlling strategy: management, accounting, and performance measurement. Oxford University Press, 2005. p. 125-150.

HAIR JR., J. F. et al. A primer on partial least squares structural equation modeling (PLS-SEM). Thousand Oaks, CA: Sage Publications, Inc., 2014.

HYVÖNEN, J. Strategy, performance measurement techniques and information technology of the firm and their links to organizational performance. Management Accounting Research, v. 18, p. 343-366, 2007.

ITTNER, C. D.; LARCKER, D. F. Assessing empirical research in managerial accounting : a value-based management. Journal of Accounting and Economics, v. 32, p. 349-410, 2001.

ITTNER, C. D.; LARCKER, D. F.; MEYER, M. W. Subjectivity and the weighting of performance measures: evidence from a balanced scorecard. The Accounting Review, v. 78, n. 3, p. 725-758, 2003. 
KAPLAN, R. S.; NORTON, D. P. Balanced scorecard: translating strategy into action. Boston: Harvard Business School Press, 1996.

KOBER, R.; NG, J.; PAUL, B. J. The interrelationship between management control mechanisms and strategy. Management Accounting Research. v. 18, p. 425-452, 2007.

KOBERG, C. S.; DETIENNE, D. R.; HEPPARD, K. A. An empirical test of environmental, organizational, and process factors affecting incremental and radical innovation. Journal of High Technology Manegement Research, v. 14, p. 21-45, 2003.

LAFORET, S. Size, Strategic and market orientation effects on innovation. Journal of Business Research, v. 61, p. 753-764, 2008.

LU, T.; CHEN, J. Incremental or radical ? A study of organizational innovation: an artificial world approach. Expert Systems With Applications, v. 37, n. 12, p. 8193-8200, 2010.

MACINTOSH, N. B. Management accounting and control systems: an organizational and behavioral approach. United Kingdom: John Wiley \& Sons Ltd., 1995.

MACINTOSH, N. B.; QUATTRONE, P. Management accounting and control systems: an organizational and sociological approach. 2. ed. United Kingdom: John Wiley \& Sons Ltd., 2010 .

MAGALHÃES, M. F. Inovando para durar. In: J. C. C. Terra (Ed.). Inovação quebrando paradigmas para vencer. São Paulo: Saravia, 2007. p.41-54.

MALERBA, F. How and why innovation differs across sectors. In: FAGERBERG, J.; MOWERY, D. C.; NELSON, R. R. (Eds.). The Oxford handbook of innovation. Oxford: Oxford University Press, 2005. p. 380-406.

MAVONDO, F. T. Regulation, deregulation, and free market: the food nanufacturing industry in Zimbabwe. Journal of Business Research, v. 50, n. 3, p. 305-319, 2000.

MERCHANT, K. A.; VAN DER STEDE, W. A. Management control systems: performance measurement, evaluation and incentives. 2. ed. Essex: Prentice Hall, 2007.

MILES, R.; SNOW, C. Organizational strategy, structure, and process. New York: McGraw- Hill, 1978.

;_. Organizational strategy, structure, and process. Stanford: Stanford University Press, 2003.

MILLER, D.; FRIESEN, P. H. A longitudinal study of the corporate life cycle. Management Science, v. 30, n. 10, p. 1161-1183, 1984.

MORGAN, R. E.; STRONG, C. A. Business performance and dimensions of strategic orientation. Journal of Business Research, v. 56, n. 3, p. 163-176, 2003.

NARANJO-GIL, D.; HARTMANN, F. Management accounting systems , top management team heterogeneity and strategic change. Accounting, Organizations and Society, v. 32, p. 735-756, 2007. 
NARANJO-GIL, D.; MAAS, V.; HARTMANN, F. How CFOs determine management accounting innovation: an examination of direct and indirect effects. European Accounting Review, v. 18, n. 4, p. 667-695, 2009.

NETEMEYER, R. G.; BEARDEN, W. O.; SHARMA, S. Scaling procedures: issues and applications. Sage Publications, 2003.

NGO, L. V.; O'CASS, A. Innovation and business success: the mediating role of customer participation. Journal of Business Research, v. 66, n. 8, p. 1134-1142, 2013.

PORTAL BRASIL NET. Cotações diárias para o mês de dezembro de 2009. Disponível em: <http://www.portalbrasil.net/2009/economia/dolar_riscopais_dezembro.htm>. Acesso em: 16 dez. 2013.

OYADOMARI, J. C. T. et al. Management control systems: comparative case study in Brazilian innovatives companies. Revista Universo Contábil, v. 6, n. 4, p. 21-34, 2010.

REVELLINO, S.; MOURITSEN, J. The multiplicity of controls and the making of innovation the multiplicity of controls and the making of innovation. European Accounting Review, v. 18, n. 2, p. 341-369, 2009.

RINGLE, C. M.; WENDE, S.; WILL, A. SmartPLS 2.0 M3 (beta). Germany: University of Hamburg, 2005. Disponível em: <http://www.smartpls.de>. Acesso em: 23 dez. 2013.

ROGERS, E. M. Diffusion of innovations. New York: The Free Press, 1995.

SIMONS, R. Accounting control systems and business strategy: an empirical analysis. Accounting, Organizations and Society, v. 12, n. 4, p. 357-374, 1987.

SIMONS, R. Levers of control: how managers use innovative control systems to drive strategic renewal. Boston: Harvard Business Press, 1995.

TUSHMAN, M. L.; ANDERSON, P. Technological discontinuities and organizational environments. Administrative Science Quarterly, v. 31, p. 439-486, 1986.

UN, C. A. Journal of engineering and an empirical multi-level analysis for achieving balance between incremental and radical innovations. Journal of Engineering and Technology Management, v. 27, n. 1-2, p. 1-19, 2010.

VARADARAJAN, R. Fortune at the bottom of the innovation pyramid: the strategic logic of incremental innovations. Business Horizons, v. 52, n. 1, p. 21-29, 2009.

VERONA, G. A resource based view of product development. Academy of Management Review, v. 24, n. 1, p. 132-142, 1999.

WELSCH, G. A.; HILTON, R.; GORDON, P. Budgeting: profit planning and control. 5. ed. Prentice Hall College Div, 1988. 